\title{
A flawed portrait. The image of Zofia Kossak in the accounts of former Birkenau female internees
}

Zofia Kossak's 1946 book entitled Z otchtani, together with Smoke over Birkenau by Seweryna Szmaglewska, Przeżyłam Oświęcim by Krystyna Żywulska, and the stories by Tadeusz Borowski, are the first literary camp testimonies. The text written by the popular novelist, who not only due to her pre-WWII output (in 1936 she received the Golden Laurel of the Polish Academy of Literature), but also as a result of her engagement in the activities of the Polish Underground State during the Nazi occupation, immediately acquired the status of the voice of the moral role model. Therefore, when it received a devastating criticism in early 1947 by a young poet and a debuting prose writer, Tadeusz Borowski, ${ }^{1}$ there occurred not as much a confusion among the intellectual elite of that time, as an open attack on the author of Pożegnanie z Maria, mainly by the writers and journalists who belonged to the Catholic stream, the most esteemed representative of which was the creator of Front Odrodzenia Polski (Poland Rebirth Front), i.e. Kossak. ${ }^{2}$

To begin with, let me restate the accusations Borowski posed against Kossak's camp account. A short recapitulation of those will prove useful to understand the recollections of former female internees who, during their internment at Birkenau, met the author of Krzyżowcy. The records of their experiences and remarks often resonated with the tone of the article entitled Alicja w krainie czarów [Alice in Wonderland].

${ }^{*}$ Ph.D.; Section for Cultural History, Institute of Polish Culture, University of Warsaw, 00-927 Warsaw 26/28 Krakowskie Przemieście St.; j.kowalska-leder@uw.edu.pl.

${ }^{1}$ T. Borowski, “Alicja w krainie czarów”, Pokolenie 1947, issue 1.

${ }^{2}$ Cf. T. Drewnowski, Ucieczka z kamiennego świata. O Tadeuszu Borowskim, PIW, Warsaw 1972; S. Buryła, "Na antypodach tradycji literackiej. Wokół «sprawy Borowskiego»", Pamiętnik Literacki 1998, col. 4; D. Kulesza, Dwie prawdy. Zofia Kossak i Tadeusz Borowski wobec obrazu wojny w polskiej prozie lat 1944-1948, Trans Humana, Białystok 2006. 
The first accusation formulated there applied to the unreliable presentation of camp reality, as if the author knew nothing of it, which resulted in many topographic, factual, and lexical errors. Secondly, Borowski criticised her for the false description of the attitudes of the women at Birkenau; Kossak idealised Polish women, Catholic Poles in particular, and demonised German women, functionary internees in particular. Thirdly, the author of Alicja w krainie czarów considered untruthful the placement of the camp reality on the metaphysical level - more specifically in relation to Christian values which, in the light of Kossak's recollections, were supposed to emerge victorious from the test the camp had offered. That axial plot of $Z$ otchlani, Borowski defined bluntly as pseudo-mysticism. In his article, one will also find an objection to excessive moral preaching, which was reflected in the incessant prompting of readers as to what they should feel while reading the book. Thus Borowski wrote about the author of $Z$ otchtani: "she constantly feels the presence of the readers, every few pages speaks to them, tries to suggest the proper reaction, anticipate their disbelief or surprise, explain to them the simplest of facts as if they were all born yesterday, or have just returned from a six-year-long emigration". ${ }^{3}$ At the end of his article Borowski raised the fundamental issue, one, it seems, not entirely understood by his contemporary readers, i.e. he defined the ethical dimension of a camp testimony, which had nothing to do with the moral classification of the experiences described there:

Let me clarify this: no one will catch me accusing the author of $Z$ otchtani that she went through the camp in an unethical way. I only hold against her, and very much so, the fact that she did not have the courage to introduce herself into the story, and judge herself. [...] Furthermore, I believe one cannot write about Auschwitz in an impersonal manner. The first and foremost responsibility of Auschwitzers is to offer an account of what the camp was - of course, but may they not forget that the readers reading their accounts, and having trudged through all the atrocities, will always ask: all right, but how did it happen that it was you who survived? There is no point debating it further, proving that it was reasonable to provide from the packages gradually, or fulfil some Christian services. It's high time: tell everyone the story of how you bought a spot in the hospital, in good kommandos, how you pushed Muselmanns into the stacks, how you bought women and men, what you did in Unterkunfts, Kanadas, Krankenbaums, in the Gypsy camp, tell everyone that, and many other minor things, tell everyone about a regular day in the camp, about its organisation, about the hierarchy of fear, about the solitude of every human being. But write that it was you who did that! That the part of the grim fame of Auschwitz belongs to you, too! don't tell me it doesn't! ${ }^{4}$

Zofia Kossak's book is extremely different from the Auschwitz stories in which Borowski intentionally, and, one could say, without a speck of mercy for himself, fulfilled his own project of a camp testimony. At its centre, there lies a personal narrative intertwined with a first-person narration, offered from the

\footnotetext{
${ }^{3}$ T. Borowski, op. cit., p. 9.

${ }^{4}$ Ibid.
} 
perspective of a young internee by the name of Tadek, who, as it is suggested there, bears Borowski's number tattooed on his forearm. Z otchlani is closest to the auctorial model of narration, where the narrator, like the readers, remains outside the presented world, at the same time presenting extensive competences within the issues she/he discusses. ${ }^{5}$ She/he is an intermediary between the readers and the presented world, in which she/he does not participate at all, or does so to a very limited extent. Therefore, Kossak's book offers no information regarding the circumstances of her arrest, how long she was interned in KL Auschwitz-Birkenau, and no answer to the question: "how did it happen that it was you who survived?"

Based on various sources, Dariusz Kulesza was able to reconstruct the stages of the writer's internment in Birkenau, where she remained from October 1943 until April 1944. Kossak spent the first month in so-called quarantine, and when in late-December she got sick with typhoid fever, she was moved to the Revier, i.e. the camp hospital. Her convalescence lasted without any interruptions until she was transported out of the camp to be held at Pawiak, from where was freed, thanks to the efforts of the Government Delegation at the end of July 1944. As indicated in the extensive survey by the author of Dwie prawdy, the published memoirs and accounts which referred to Zofia Kossak's activities and attitude during WWII possess a dominant hagiographic tone. Her colleagues from the underground, and other people who came into contact with her confessed that even many years later they still remained captivated by her. Zofia Kossak impressed with her courage and integrity, and her charisma was infectious. She became etched in the memories of many as being extremely resilient both mentally and physically, as well as sensitive to the needs of those around her, caring, supportive, encouraging, and inspiring. ${ }^{6}$ In the testimonies which helped form the legend of Zofia Kossak, one finds many emotional and approving epithets: "a luminous figure, the noblest flame, the underground's inspiration, the bravest of the brave, burning with courage and creative urge, a soldier woman, the heroic «Weronika», the fearless «Aunt», our national treasure". ${ }^{7}$

In the archive of the Auschwitz-Birkenau State Museum, there have survived previously unpublished accounts by former female internees of the camp, who among many other topics and people also referred to Zofia Kossak. ${ }^{8}$ The authors

${ }^{5}$ Cf. F. Stanzel, "Typowe formy powieści”, trans. R. Handke, in: Teorie form narracyjnych w niemieckim kręgu językowym, R. Handke (ed.), Wydawnictwo Literackie, Krakow 1980, pp. 243-287.

${ }^{6}$ Cf. Zofia Kossak, M. Pałaszewska (ed.), Muzeum Niepodległości w Warszawie, Fundacja Archiwum Polski Podziemnej 1939-1956, Warsaw 1992; M. Pałaszewska, "Zofia Kossak w latach II wojny światowej”, Niepodległość i Pamięć 1995, issue 3; M. Komar, W. Bartoszewski, Skad pan jest? Wywiad rzeka, Świat Książki, Warsaw 2006.

${ }^{7}$ Vide D. Kulesza, op. cit., p. 27.

${ }^{8}$ I cannot exclude the possibility that some fragments of the accounts quoted in this article have appeared in print. It is certain, however, that they have never become mainstream testimonies related to Zofia Kossak's internment in KL Auschwitz-Birkenau. 
of the majority of those, recorded from the early-1960s until the end of the 1990s, during their internment in the camp, came into contact with Kossak at block 17, in the Revier, i.e. the hospital, where the creator of FOP spent more than half of her seven-month internment in Birkenau. ${ }^{9}$ Their accounts include recurring remarks about Zofia Kossak's isolation from the rest of the camp, and her extremely limited insight into the living conditions of a regular internee of a Lager. Her isolation was even further amplified by the fact that, first of all, the Revier constituted a relatively safe area separated from the rest of the camp, and, secondly, the popular writer, Catholic activist, and undisputed moral leader of the Polish underground received special care from the camp resistance, as a result of which her living conditions were incomparably better than those of other female internees, even those referred to the hospital. In an account recorded in the mid-1990s, Janina Woynar-Sujecka, who met Zofia Kossak at the hospital block, emphasised its special situation within the camp: "There is very little I can tell you about the things which occurred outside the hospital or even block 17. We lived there, to some extent, in isolation, and we rarely got word from the outside". ${ }^{10}$ That aspect, though regarding the quarantine block, was indicated by Eugenia Kurzelowa, who met Zofia Kossak during the first month she spent in the camp. Once again, an internee talked about a type of enclave within the area of Birkenau: "The quarantine block did not even have roll calls - it was all about rest", ${ }_{11}$ Kurzelowa reminisced.

Apparently, the majority of Zofia Kossak's internment in the camp happened in isolation from what could be considered typical aspects of a Lager experience, as it was described even in the earliest testimonies of former internees. Those included information on arriving transports, smoking stacks, the terrifying sight of the Muselmanns, about the work of external kommandos, as well as severe penalties exacted on internees or pseudo-scientific experiments to which they fell victim. Some of those topics can be found in $Z$ otchtani. It is certain that they were not based on Zofia Kossak's eye witness experiences, rather on stories she heard. What is important, though, is that the writer not only translated them into the language of literature, but, most of all, offered an in-depth interpretation of them, and placed them within the frames defined by the limitations of her world-view, imagination, and religious sensitivity. As a result - as noted by Dariusz Kulesza $-Z$ otchtani ought to be read, unlike, e.g. Borowski's stories, as a testimony of faith, not as a testimony of a camp experience. ${ }^{12}$ That position can be confirmed by the account of Irena Mann, who met Kossak in the camp hospital. She reminisced that the writer's presence in Birkenau became a public secret even earlier, even though having been arrested with false documents as Zofia Śliwińska she was not

\footnotetext{
${ }^{9}$ Cf. D. Kulesza, op. cit., p. 25.

${ }^{10} \mathrm{~J}$. Wojnar-Sujecka, Oświadczenia 1995, vol. 130.

${ }^{11}$ E. Kurzelowa, Oświadczenia 1963, vol. 36.

${ }^{12}$ D. Kulesza, op. cit., pp. 76-79.
} 
singled out by the camp authorities. For the female internees in the Revier, contact with Zofia Kossak was a very important experience, as they associated with her a hope that the world, thanks to the talent of the renowned writer, would someday learn the truth about what happened in Auschwitz.

Because we appreciated her outstanding talent, we the "old" internees tried to tell her what it was like at the beginning. But she always said: ladies, it's impossible that it has ever been worse than it is now. We said: Mrs. Zofia, if you don't believe us, who will? Now there's water, light, we're getting packages. Lagerstrasse is paved, while earlier we waded knee-deep in mud, you can get some clothes from the Effektenkammer. When compared to 1942, that was progress, for a concentration camp. However, Mrs. Zofia was not able to believe in everything. Truth be told, she was cared for from the very start, she wasn't even that hungry, she did not leave for work, and though she was in the camp, she didn't experience it as the others did, because from the very start she was cocooned. Szmaglewska, on the other hand, did experience the camp. She worked in various kommandos. And if you could say that Szmaglewska's book Smoke over Birkenau is a documentary, and that there is no exaggeration, then $Z$ otchtani is according to us, "old" internees - flat. Krystyna Żywulska's book is also good. But we were disappointed by Kossak-Szczucka's book; and we counted so badly on her writing a good book about the camp, we believed so much in her. I was one of those who wanted to give the whole truth about what we saw when we came to the camp. What the camp and life looked like at the beginning, while she kept saying: it's impossible. ${ }^{13}$

The writer's reaction to the stories of her fellow internees as described by Irena Mann brings to mind the old Buddhist saying accompanied by the well-known three-monkey figurine, which visualises the motto: whoever sees no evil, hears no evil, speaks no evil, protects oneself from it. The quoted account indicates exactly such a gesture by Zofia Kossak, who covered her ears not to hear the unimaginable nightmare. It could be understood as an attempt at defending a crystallised vision of the world, with which the writer entered the camp. Note, she was over fifty at that time, she had already become a widow, and remarried, she had given birth to four children, one of which had died. She possessed vast prose expertise, for many years she had been engaged in community work, and, most of all, her entire life up to that point had been based on the firm foundations of the Catholic faith. As noted by Dariusz Kulesza,

Zofia Kossak protected herself from the camp (she protected her readers from it), preventing herself (and, in turn, her readers as well) from seeing it. [...] she did not write how to pass through the camp because she had never entered it - she never yielded to it, she never enabled it to become present. ${ }^{14}$

The matter was completely the opposite in the case of Tadeusz Borowski, who was sent to the camp having turned twenty. The sum of his major life experiences

\footnotetext{
${ }^{13}$ I. Mann, Oświadczenia 1998, vol. 143.

${ }^{14}$ D. Kulesza, op. cit., p. 78.
} 
included at that time: his first serious love, a collection of poems, and underground Polish studies. As justly stressed by the author of Dwie prawdy, "Borowski's camp prose (unlike $Z$ otchtani) was not created through subjecting the concentration reality to that which defined the pre-camp life of Vorarbeiter Tadek". ${ }^{15}$ His perception of the camp was not determined by previously crystallised categories; on the contrary: having learnt the rules at Auschwitz-Birkenau, he cast them on the world outside the wires.

One could say that, unlike Zofia Kossak, Borowski while in the camp constantly had his eyes wide open and a keen ear, which he used to take in all the stories about everything he could not see himself. In his stories he presented, i.a. the dynamics of the changes which occurred from the moment of establishing the camp to the period Borowski knew from experience. "Obviously, Auschwitz and Birkenau went from bad to good", ${ }^{16}$ thus in Ludzie, którzy szli he briefly defined the essence of the changes in camp life, to which the "old" internees tried to draw Zofia Kossak's attention. Then Borowski explained that the changes were such that, e.g. the internees were beaten and killed less frequently during their work in kommandos, sleeping on the floor ended when bunks were built, roll calls became shorter, Poles began to receive packages, and internees were even allowed to wear civilian clothes. Borowski stressed, though, that the evolution described by him did not apply to the entirety of the camp. The story of Ludzie, którzy szli happened in the spring of 1944, i.e. in the period of the so-called Hungarian transports, which the author did not discuss directly. He did mention that the women who managed to survive selection, were referred to the yet undeveloped part of Birkenau:

In the Persian Market, time moved backwards. We watched once again Auschwitz from 1940. Women greedily slurped the soup which no one in our blocks would eat. They reeked of sweat and women's blood. They stood the roll call from five in the morning. It was almost nine when they finally counted them. Then they got cold coffee. ${ }^{17}$

Borowski also clearly stressed the civilisational chasm dividing the two sections of the KL Auschwitz-Birkenau complex. "People love Oświęcim, they state proudly: «At our place, in Auschwitz...»; ${ }^{18}$ that is one of those sentences which perplex the readers who are used to martyrological narratives, and expect that is what they will be reading when taking up the stories of the author who survived the Lager. Yet slowly, as they immerse themselves in them, they have the chance to understand the reasons of the internees" "love" for Auschwitz, and their "pride" combined with contempt and pity when they viewed the wretched souls

${ }^{15}$ Ibid., p. 79.

${ }^{16}$ T. Borowski, "Ludzie, którzy szli”, in: ibid., Wspomnienia. Wiersze. Opowiadania, PIW, Warsaw 1974, p. 136.

${ }^{17}$ Ibid., p. 137.

${ }^{18}$ T. Borowski, “U nas, w Auschwitzu...,", in: ibid., Wspomnienia ..., p. 91. 
in Birkenau, where in comparison to the original camp the conditions were primitive, and most of all: where the Holocaust machine was operating in full force.

In $Z$ otchlani it would be futile to seek any information presenting the dynamics of the changes of the Auschwitz-Birkenau camp, and its internal differentiation, often surprising contradictions which did not offer any obvious functional justification. The lack of any deeper knowledge of the reality is visible even in the first words of Zofia Kossak's introduction, in which the readers learn that Birkenau was a women's Lager, while Auschwitz was for men. ${ }^{19}$ Based on Irena Mann's account, it was mainly the superficial description of camp life which caused the former female internees to consider $Z$ otchtani as "flat", unlike the recollections of Szmaglewska or Żywulska. Though they did not evaluate it as harshly as Borowski did, i.e. as "bad and false, and most of all hopelessly feeble in literary terms", ${ }^{20}$ their opinions, provided in the quoted account, could be considered a type of a footnote to Alicja w krainie czarów, which confirmed the accusations formulated therein.

Though Borowski clearly stated that his criticism only applied to the book ("no one will catch me accusing the author of $Z$ otchlani that she went through the camp in an unethical way"), ${ }^{21}$ some of the former female internees, offering their accounts for the museum archive, displayed a negative or visibly reserved approach when discussing Zofia Kossak's presence in the camp. The previously mentioned Janina Woynar-Sujecka, who stayed at the hospital block with the writer, remembered with warmth Stanisława Leszczyńska, the famous midwife from Birkenau, and Seweryna Szmaglewska because, e.g. she divided between the patients the food packages she received from her family.

Zofia Kossak-Szczucka did not make the best impression on me. In my opinion, she was too arrogant, and her behaviour bore the signs of self-interest and egoism. She managed to gather around herself a circle of friends, who treated her as a highly exceptional person, and continued to shower her with praise. In her bunk, she had a clean white bed sheet, and, in general, she was ensured protective conditions. ${ }^{22}$

A similar tone resonates in the account by Maria Oyrzyńska of 1982. When describing the living conditions at the hospital block, she recalled the intense cold, which the female internees tried to counter, risking their lives when trying to "acquire" some wood at night.

When Zofia Kossak-Szczucka stayed at our block, it was for her they heated the stove, and occupied spots on the grate with her pots, pushing the pots of other internees away, because all day long for Mrs. Zofia there was water heating, either for washing, or for the hot water

\footnotetext{
${ }^{19}$ Z. Kossak, Z otchłani, Książka i Wiedza, Warsaw 2004, p. 5.

${ }^{20}$ T. Borowski, "Alicja w krainie czarów”, p. 9.

${ }^{21}$ Ibid.

${ }^{22} \mathrm{~J}$. Wojnar-Sujecka, op. cit.
} 
bottle so that she could warm her feet, or soup, or potatoes, or potato dumplings were cooked, or potato pancakes were fried. ${ }^{23}$

The accounts by Janina Woynar-Sujecka and Maria Oyrzyńska not only confirm the fact that Zofia Kossak, being an important figure in the Polish underground, remained under the care of the camp resistance, which tried to protect her from the experiences shared by regular internees of Auschwitz-Birkenau. Those also indicate that in the eyes of at least some of the female internees the manner in which the writer accepted the help of the underground was unethical - laced with egoism, and indifference to the suffering of others. Such perceptions could have been a result of the expectations they had towards a person known for propagating Christian values, such as compassion, being sensitive of the suffering of those who are weaker, and, finally, readiness to sacrifice oneself emulating Christ. Those values shaped not only the pre-WWII and Nazi occupation writings of Zofia Kossak, but also constituted the religious-ethical foundation on which she based her camp testimony. $Z$ otchlani, written with the grand educational project for the postWWII world in mind, was supposed to offer proof that Christian values emerged victorious from the test they were subjected to in the cruel and inhuman conditions which existed in Birkenau. There is no basis for stating that the position was formulated in a dishonest manner. The increased protection which Kossak received in the Lager (care of the resistance on the one hand, and her own self-defence from learning about camp reality on the other) prevented her from noticing that she herself had become part of the system of morally false alternatives, while, in fact, that diagnosis constituted, according to Andrzej Werner, the basis of Borowski's Auschwitz stories. ${ }^{24}$ They presented the camp as a system of alternatives, which were false due to the fact that regardless of which one was chosen, they always remained in opposition to life - one's own or someone else's. That was mainly due to the fact that the camp constituted a closed system of distribution of food, medication, and other resources necessary for survival. Zofia Kossak did not understand, and, as one might assume, did not want to understand that a clean sheet, warm soup, a hot water bottle, and water for washing heated on the stove meant decreasing the chances of survival of other internees at the hospital block.

Among the accounts by Zofia Kossak's former fellow female internees collected in the archive of the Auschwitz-Birkenau Museum one will also find such which resonate the hagiographic tone of the publications devoted to the "bravest of the brave" of the Polish underground. The writer is presented in those as the stimulator of cultural life, as well as the promoter of religious practices bringing solace to other female internees. In her 1963 recollections, the previously mentioned Eugenia Kurzelowa reminisced that on the first days of Kossak's

${ }^{23}$ M. Oyrzyńska, Oświadczenia 1982, vol. 98.

${ }^{24}$ A. Werner, Zwyczajna apokalipsa. Tadeusz Borowski i jego wizja świata obozów, Czytelnik, Warsaw 1971. 
internment in the camp: "There were around thirty of us women in the quarantine block. That was where I met Kossak-Szczucka, who under the assumed name of Zofia Śliwińska comforted other internees by telling us about historical events and legends". ${ }^{25}$ A similar piece of information can be found in the 1970 account by Stanisława Rachwałowa, who before internment was an intelligence operative of the Union of Armed Stuggle (ZWZ), and at the camp - a resistance activist, who received the order to take care of not only Zofia Kossak, but also Celina Mikołajczykowa. She recalled that the camp underground sent to Warsaw a request for consent to organise Kossak's escape. The response was negative mainly due to the fact that her disappearance from the camp could trigger the deaths of other female internees, should collective responsibility have been applied. There was, however, one more reason an attempt to escape was not made: "In addition, Zofia Kossak, referred to as Auntie Zosia, was needed in the camp. She knew how to comfort other female internees. In 1943, she organised Christmas at the camp, in which approximately 80 people participated. She gave a beautiful speech, she sang Christmas carols" ${ }^{26}$ Rachwałowa's account fits the same stream as the printed memoir of Maria Przełęcka, in which the writer's constant immersion in prayer is particularly riveting: "in every moment of free time, she prayed silently, while on Sunday she «said» in Polish the entire holy mass in lowered voice, if even a small group had formed. Unforgettable moments" ${ }^{27}$ Zofia Kossak as the stimulator of religious life in the camp, regularly practising also silent individual prayer, did not evoke admiration and enthusiasm in all the internees. One mention of that can be found in the 1980 account by Maria Slisz-Oyrzyńska, who, significantly enough, described not only her own feelings, but also the reactions of a bigger group of women who remained at the station: "Zofia Kossak-Szczucka (Śliwińska), as she lied in our block 17, prayed all day round. Incessantly, up to the point of our irritation. She prayed in a lowered voice. Mostly the rosary (even today I can still see the blue rosary)" ${ }^{28}$ One confirmation of the fact that religious practices could be considered by the surrounding people as a form of bothersome sanctimony can be found in Borowski's This Way for the Gas, Ladies and Gentlemen. One of its scenes takes place in a crowded barracks, where in the lower bunks sick and starving internees are squeezed in, and among them a rabbi who, having covered his head with a piece of cloth, reads the Hebrew prayerbook, "wailing loudly, monotonously". ${ }^{29}$ The narrator reacts to it with distinct irritation: "Can't somebody

${ }^{25}$ E. Kurzelowa, op. cit.

${ }^{26}$ S. Rachwałowa, Oświadczenia 1970, vol. 69.

${ }^{27}$ M. Przełęcka, "Zofia Kossak jaką pamiętam (wspomnienia łączniczki)”, in: Zofia Kossak, op. cit., p. 45.

${ }^{28}$ M. Slisz-Oyrzyńska, Oświadczenia 1980, vol. 94. The author signed the previously quote account of 1982 using only one part of her surname. Vide M. Oyrzyńska, Oświadczenia 1982, vol. 98.

${ }^{29}$ T. Borowski, "Proszę państwa do gazu", in: ibid., Wspomnienia ..., p. 172. [English version: Borowski, T. This Way for the Gas, Ladies and Gentlemen. New York 1967] 
shut him up? He's been raving as if he'd caught God himself by the feet" ${ }^{30}$ Maria Slisz-Oyrzyńska's account indicates that similar feelings could have been evoked by Zofia Kossak's prayers, which did not offer comfort to everyone around her.

The accounts of Zofia Kossak's former fellow female internees quoted in this article diverge considerably from the hagiographic tone which has dominated the recollections devoted to her. They could, of course, be considered as voices supporting Borowski's critical position, yet their biggest value lies in bringing us closer to answering the question he posed, i.e. how did Zofia Kossak manage to survive the camp? The fact that she remained under the care of the resistance was known from other sources, but the internees revealed the practical dimension of that aid, and its consequences for the women surrounding the writer. They also indicate how she protected herself from becoming "infected" with the Lager, and, at the same time, they help realise that even spiritual self-defence could have resulted in negative consequences for other internees within the system of morally false alternatives.

\section{Bibliography}

Unpublished sources from the Archive of the Auschwitz-Birkenau State Museum:

Kurzelowa Eugenia, Oświadczenia 1963, vol. 36.

Mann Irena, Oświadczenia 1998, vol. 143.

Oyrzyńska Maria, Oświadczenia 1982, vol. 98.

Rachwałowa Stanisława, Oświadczenia 1970, vol. 69.

Slisz-Oyrzyńska Maria, Oświadczenia 1980, vol. 94.

Wojnar-Sujecka Janina, Oświadczenia 1995, vol. 130.

\section{Published sources:}

Borowski Tadeusz, “Alicja w krainie czarów”, Pokolenie 1947, issue 1, p. 9.

Borowski Tadeusz, Wspomnienia. Wiersze. Opowiadania, PIW, Warsaw 1974.

Buryła Sławomir, "Na antypodach tradycji literackiej. Wokół «sprawy Borowskiego»", Pamiętnik Literacki 1998, col. 4, pp. 99-123.

Drewnowski Tadeusz, Ucieczka z kamiennego świata. O Tadeuszu Borowskim, PIW, Warsaw 1972. Komar Michał, Bartoszewski Władysław, Skad pan jest? Wywiad rzeka, Świat Książki, Warsaw 2006.

Kossak, Z otchłani, Książka i Wiedza, Warsaw 2004.

Kulesza Dariusz, Dwie prawdy. Zofia Kossak i Tadeusz Borowski wobec obrazu wojny w polskiej prozie lat 1944-1948, Trans Humana, Białystok 2006.

Pałaszewska Mirosława, "Zofia Kossak w latach II wojny światowej”, Niepodległość i Pamięć 1995, issue 3, pp. 49-94.

Stanzel Franz, "Typowe formy powieści”, trans. Ryszard Handke, in: Teorie form narracyjnych w niemieckim kręgu językowym, Ryszard Handke (ed.), Wydawnictwo Literackie, Krakow 1980, pp. 237-297.

Werner Andrzej, Zwyczajna apokalipsa. Tadeusz Borowski i jego wizja świata obozów, Czytelnik, Warsaw 1971.

Zofia Kossak, Mirosława Pałaszewska (ed.), Muzeum Niepodległości w Warszawie, Fundacja Archiwum Polski Podziemnej 1939-1956, Warsaw 1992.

\footnotetext{
${ }^{30}$ Ibid.
} 


\section{A flawed portrait. \\ The image of Zofia Kossak in the accounts of former Birkenau female internees}

\section{(Summary)}

The article indicates how the figure of Zofia Kossak has been recorded in the unpublished accounts by former KL Auschwitz-Birkenau female internees who during their internment came into contact with the famous writer and activist of the Polish Underground State. Their testimonies diverge from the hagiographic tone which has dominated the known stories of Kossak's camp experiences, rather resembling Tadeusz Borowski's infamous post-WWII article entitled Alicja w krainie czarów.

Key words: KL Auschwitz-Birkenau; Zofia Kossak; post-WWII accounts by female internees; Tadeusz Borowski 